\title{
An Experimental Investigation by Utilizing Plastic Waste and Alccofine in Self-Compacting Concrete
}

\author{
Abdul Sami Kohistani and Khushpreet Singh \\ Department of Civil Engineering, Chandigarh University, Mohali - 140413, Punjab, India; \\ sam7kohistani@yahoo.com, Khushpreet.civil@cumail.in
}

\begin{abstract}
Background/Objective: This study aimed to investigate in properties of Self Compacting Concrete (Fresh \& Hardened properties) by utilizing Alccofine and PET fibers as a replacement of cement and fine aggregate respectively, for enhancing the workability and durability of SCC. Methods/Statistical Analysis: The Mix design was done by Nan-Su method. In this investigation an experimental program carried out for M30 grade of concrete in SCC mixes with various percentage of plastic waste from $0.5 \%$ up to $1.25 \%$ as replacement of fine aggregate and $10 \%$ Alccofine as cement replacement. Different tests in fresh properties of SCC conducted for evaluation of workability such as (slump flow, V funnel, L box and U box) and in hardened properties of SCC (compressive, flexural, tensile strength, sulfate attack, abrasion resistance, XRD, SEM \& EDS) were performed for evaluating the strength and durability of SCC. Finding: From the test results it observed that utilizing of $1 \%$ plastic waste and $10 \%$ Alccofine have best performance in workability and strength of self compacting concrete and it increase the durability of SCC. Applications/Improvement: Combination of Alccofine and PET fibers can be used in SCC as a strength and durability enhancer for having a suitable concrete and sustainable construction.
\end{abstract}

Keywords: Alccofine, Durability, Plastic Waste, Self-Compacting Concrete, Workability

\section{Introduction}

Self Compacting concrete is able to flow in all shapes and abstractions. This type of concrete does not need vibration. Self compacting concrete is considered as greatest concrete and development concrete in concrete technology over the years, at least from 1980 (first developed in japan) till today. SCC has more advantages than conventional concrete because of its advantages it has more usage in construction era. Self-compacting concrete is able to get compacted without any external vibration and this type of concrete contains high content of fine admixtures and super plasticizer, also it has more workability than conventional concrete and it increase the speed of construction by about $40 \%$.

\subsection{Development of SCC by Utilization of Alccofine}

An Investigation was conducted to find the effect of Alccofine by evaluation of properties of self compacting concrete for having best workability in SCC and effect of Alccofine in hardened properties of CC after 7, 28 days of curing and after experimental work the result was found that by utilizing of Alccofine self compacting concrete has more strength, this study was found that also if the

${ }^{*}$ Author for correspondence 
percentage level of Alccofine increased beyond to the optimum level the strength of SCC decreased and won't have the desired workability and durability ${ }^{2}$. Utilization of supplementary cementations for having and economical SCC in the production of this concrete can result in the major saving of cost and energy, it also improves the strength for having more durable concrete, the replacement of Alccofine by $10 \%$ in SCC had attained optimum result in strength ${ }^{3}$. A study of Alccofine and fly-ash was done to evaluate the performance of SCC so for that purpose an experimental work was conducted, and different tests were performed to achieve the result, so from results it was showing that self compacting concrete has best result with utilizing Alccofine and fly ash it increases the work ability and the durability as well.

\subsection{Development of SCC by Utilization of Plastic Waste}

An investigation on SCC was carried out by utilizing Plastic waste from PET bottles in various percentages in M30 grade of concrete, after different tests it was found that the maximum strength observed by $1 \%$ of plastic waste in all mixes and in all type of strength ${ }^{5}$. A study has been carried out to develop the performance of Self compacting concrete by utilizing plastic waste from beverage bottles after evaluating by different tests and the results showed that plastic waste in form of fibers does not has a good result workability of Self compacting concrete, but it has good performance in durability of SCC A study was developed by utilization of plastic waste in Self compacting reinforced concrete different mixes were adopted with different percentage of plastic waste from $0.25 \%$ up to $1.4 \%$ and this experimental work aimed for M40 grade of SCC, after different test it was achieved that Self compacting concrete has best strength performance by utilizing $1 \%$ plastic waste maximum compressive strength and other types of strength was achieved, if the level of percentage from $1 \%$ increase or decrease the strength also act not good at all ${ }^{\not}$. An experimental investigation was performed by using E-plastic waste as a coarse aggregate replacement in Self-compacting concrete by varying percentage from $0.25 \%$ up to $30 \%$ and from results it has been achieved that utilizing E-plastic waste has good effect in total cost and performance of self compacting concrete ${ }^{8}$. A study aimed at investigating the resistance of SCC with addition of plastic waste fibers to acid attack, from the test results as the percentage of fiber increased, weight loss percentage in compressive strength decreased when the specimens immersed in 5\% sulphuric acid by weight of water with $\mathrm{P}^{\mathrm{H}}$ of 2.0 for 30,60 and 90 days respectively ${ }^{9}$. So in this research utilization of plastic waste and Alccofine in SCC has been evaluated by using $10 \%$ Alccofine in SCC mixes as a cement replacement which is a constant percentage replacement for Alccofine in all mixes because $10 \%$ has been proved that it is a best percentage for replacement of Alccofine in SCC from literature review, and for plastic waste the percentage usage is varying from $0.5 \%$ up to $1.25 \%$ in different mixes of SCC for finding the percentage use of plastic waste in Self compacting .

\section{Experimental Investigations}

This experimental study conducted to insure the workability and durability performance of SCC by evaluating the effect of Alccofine and plastic waste.

\subsection{Materials}

\subsubsection{Cement}

Ordinary Portland cement grade 43 accepted to IS: 8112$1989^{10}$ has been used in this experimental investigation, the properties of this cement presented in Table 1.

\subsubsection{Fine Aggregate}

Fine aggregate confirming to IS 383-1970 which passes from $4 \mathrm{~mm}$ sieve with bulk density of $1525.15 \mathrm{~kg} / \mathrm{m}^{3}$ and packing factor of 1.11 has been used for this experimental study.

\subsubsection{Coarse Aggregate}

Confirming to IS: $383-1970^{11}$ are appropriate for the production of SCC. It is easy available with of size $12.5 \mathrm{~mm}$ 


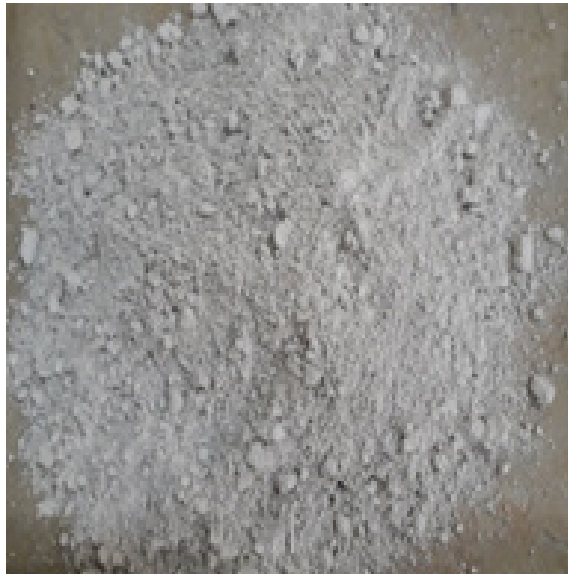

(a)

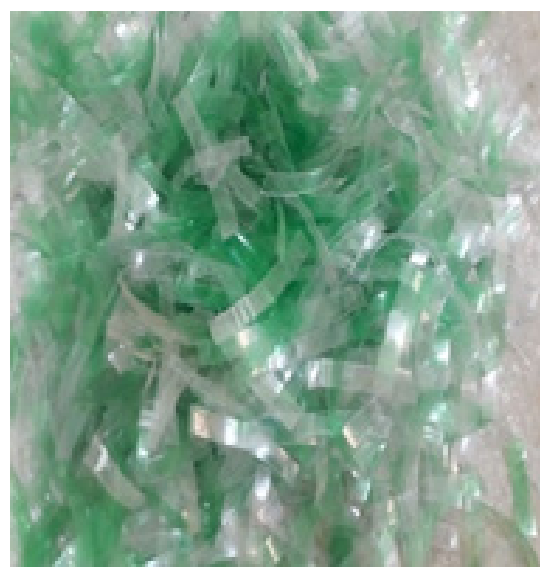

(b)

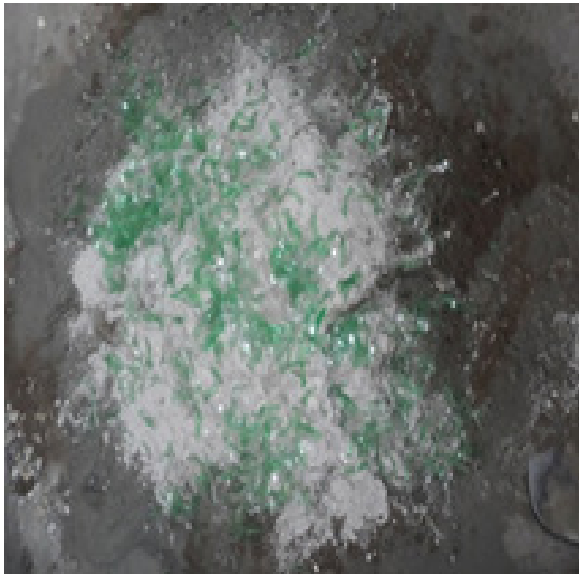

(c)

Figure 1. Alccofine 1203, Plastic waste (PET) and Mixture of material. A: Alccofine 1203 b: Plastic waste (PET) c: Mixture of materials

with bulk density of $1550.12 \mathrm{~kg} / \mathrm{m}^{3}$ and packing factor of 1.09 used for this experimental study

\subsubsection{Alccofine 1203}

Alccofine has high glass content and it can be finding from processed slag in production. Alccofine 1203 confirming to ASTM C989-99 is used, because of it is a similarity property it has been used as replacement of cement, properties of Alccofine presented in (Table 1).

\subsubsection{Plastic Waste (PET Bottles)}

For this experimental study fine plastic waste passing from $4 \mathrm{~mm}$ sieve and remaining in $1 \mathrm{~mm}$ sieve has been used and it shows in Figure 1 from polyethylene terephthalate (PET).

\subsubsection{Super Plasticizer Admixture (SP)}

Super plasticizer admixture or high range water reducer is the most important admixture with a water reduction

Table 1. Properties of Cement and Alccofine 1203 confirming to IS: 8112-1989 and ASTM C989-99

\begin{tabular}{|c|l|l|c|l|l|c|}
\hline Analysis report \% & & & $\begin{array}{c}\text { OPC } \\
\text { Cement }\end{array}$ & & & $\begin{array}{c}\text { Alccofine } \\
\mathbf{1 2 0 3}\end{array}$ \\
\hline $\mathrm{C}_{\mathrm{a}} \mathrm{O}$ & & & 60.00 & & & $61-64$ \\
\hline $\mathrm{SO}_{3}$ & & & 2.53 & & & $2-2.4$ \\
\hline $\mathrm{S}_{\mathrm{i}} \mathrm{O}_{2}$ & & & 19.50 & & & $21-23$ \\
\hline $\mathrm{Al}_{2} \mathrm{O}_{3}$ & & & 9.57 & & & $5-5.6$ \\
\hline $\mathrm{MgO}$ & & & 1.63 & & & $0.8-1.4$ \\
\hline Fe2O3 & & & 3.36 & & & $3.8-4.4$ \\
\hline $\begin{array}{c}\text { Specific gravity } \\
\text { Fineness } \\
\text { Bulk density }\end{array}$ & & & 3.15 & & & 2.8 \\
\hline
\end{tabular}


greater than $20 \%$ for SCC. For this research, modified polycarboxylic ether (Master Glenium Sky 8632) is used to improve the workability of mixes along with durability of SCC.

\subsection{Mix Proportions}

For this study five different mixes of self-compacting concrete have been designed according to (EFNARC-2005) with Nan-Su method. Four different mixes of SCC with varying percentage of plastic waste $(0.5 \%, 0.75 \%, 1 \%$, $1.25 \%$ ) as a replacement fine aggregate and $10 \%$ Alccofine as are placement of cement were designed along with control mix of conventional concrete. the mix design was adopted for M30 grade of concrete according to European guidelines and specifications for self-compacting concrete the method for design mix was Nan-Su method ${ }^{12}$. Table 2 presented the mix proportion of SCC for different mixes and Table 3 presented factors for design mix by Nan-Su method. Nan-Su method is a simple method for design mix of SCC there for is used for designing of SCC in this investigation. The procedure mix design was properly done and insured the concrete has flow ability and other desired characteristic of self-compacting concrete $\frac{13}{}$.

Table 2. Mix proportion of Self-compacting concrete with utilization of Alccofine and Plastic waste

\begin{tabular}{|c|c|c|c|c|c|c|c|c|}
\hline Mix ID & W/b & water & SP & Cement & Alccofine & PET & C. agg & F. agg \\
\hline Control Mix & 0.45 & 176.58 & - & 392.4 & - & - & 1024.16 & 812.26 \\
\hline $\begin{array}{c}10 \% \text { Alc\& 0.5\% } \\
\text { PET }\end{array}$ & 0.45 & 125.26 & 4.83 & 483.2 & 235.02 & 11.75 & 777.23 & 909.59 \\
\hline $\begin{array}{c}10 \% \text { Alc\& 0.75\% } \\
\text { PET }\end{array}$ & 0.45 & 125.26 & 4.83 & 483.2 & 235.02 & 17.62 & 777.23 & 907.31 \\
\hline $\begin{array}{c}10 \% \text { Alc\& 1\% } \\
\text { PET }\end{array}$ & 0.45 & 125.26 & 4.83 & 483.2 & 235.02 & 23.5 & 777.23 & 905.02 \\
\hline $\begin{array}{c}10 \% \text { Alc\& } 1.25 \% \\
\text { PET }\end{array}$ & 0.45 & 125.26 & 4.83 & 483.2 & 235.02 & 29.37 & 777.23 & 902.743 \\
\hline
\end{tabular}

Table 3. Factors for mix design by Nan-Su method

\begin{tabular}{|c|c|c|c|c|c|c|}
\hline $\begin{array}{c}\text { Target main } \\
\text { strength } \\
\text { (Mpa) }\end{array}$ & W/C & \multicolumn{2}{|c|}{ Coarse aggregate } & \multicolumn{2}{|c|}{ Fine aggregate } & \multicolumn{2}{c|}{ Air voids } \\
\hline & & $\begin{array}{c}\text { Bulk density } \\
\left(\mathrm{Kg} / \mathrm{m}^{3}\right)\end{array}$ & $\begin{array}{c}\text { Packing } \\
\text { factor }\end{array}$ & $\begin{array}{c}\text { Bulk density } \\
\left(\mathrm{Kg} / \mathrm{m}^{3}\right)\end{array}$ & Packing factor & 0.5 \\
\hline 38.25 & 0.45 & 1550.12 & 1.09 & 1525.15 & 1.11 & \\
\hline Quantity $\left(\mathrm{Kg} / \mathrm{m}^{3}\right)$
\end{tabular}




\subsection{Tests Methods}

The fresh properties of Self-compacting concrete were evaluated by using Slump flow test according to (EN 12350: part 8-2010 ${ }^{14}$ ) presented in Figure 2, V-funnel test according to (EN 12350: part 9-201015), L-box test (EN 12350: part 10-2010 ${ }^{16}$, U-box test in accordance to EFNARC-2005 ${ }^{17}$ to meet the desired workability and viscosity of SCC. And different test was adopted for evaluating the strength and durability of SCC. Tests such as sulfate attack test, weight loss test, XRD test, SEM \& EDS test were conducted to determine the durability of SCC mixes.

\section{Results and Discussion}

\subsection{Workability of SCC}

Workability result is presented in Table 4 . The results are showing that fresh properties of SCC mixes have best workability performance up to $1 \%$ plastic waste and $10 \%$

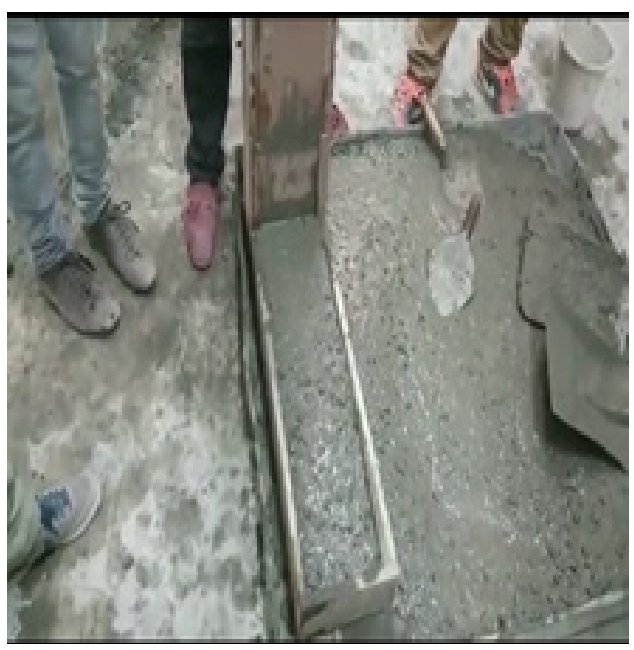

(a)

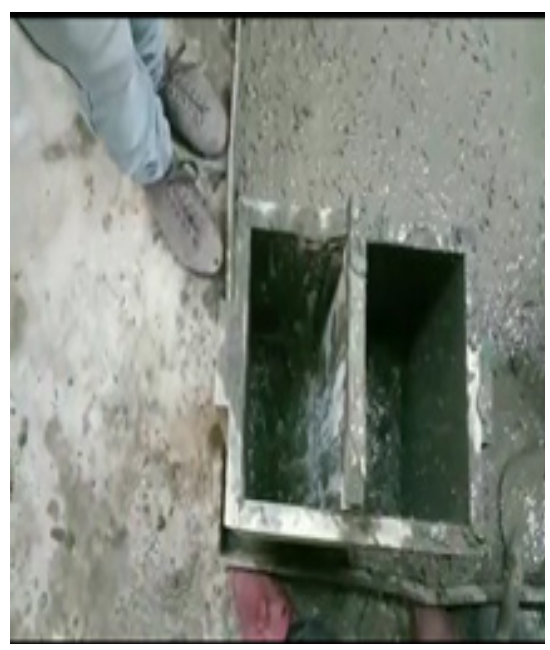

(b)

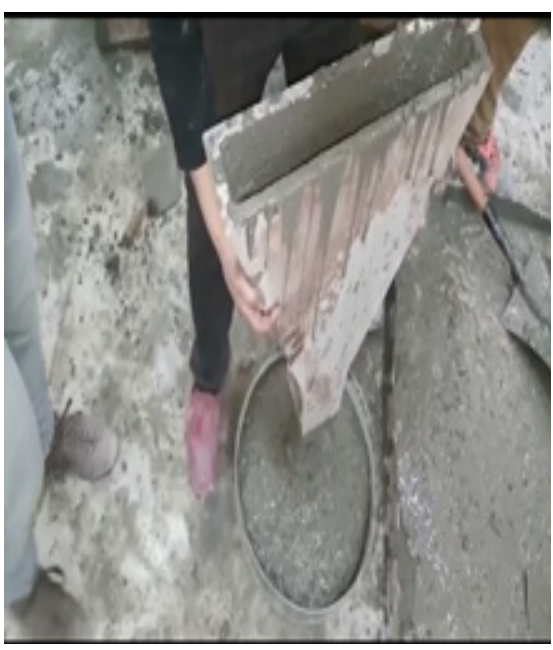

(c)

Figure 2. Tests on Fresh properties of SCC.

Table 4. Fresh properties of SCC Mixes

\begin{tabular}{|c|c|c|c|c|c|}
\hline S.No & Trail Mix & $\begin{array}{c}\text { Slump flow } \\
\text { mm (600- } \\
800)\end{array}$ & $\begin{array}{l}\text { L-Box }(\mathrm{H} 2 / \\
\text { H1) 0.8-1.0 }\end{array}$ & $\begin{array}{c}\text { U-Box }(\mathrm{H} 2 / \\
\text { H1) }<30 \\
\text { mm }\end{array}$ & $\begin{array}{l}\text { V-Funnel } \\
\text { (s) 8-12 }\end{array}$ \\
\hline 1 & $\begin{array}{c}0.5 \% \\
\text { PET, } 10 \% \\
\text { Alccofine }\end{array}$ & 610 & 1.12 & 32 & 7.5 \\
\hline 2 & $\begin{array}{c}0.75 \% \\
\text { PET, 10\% } \\
\text { Alccofine }\end{array}$ & 670 & 0.81 & 25 & 7.9 \\
\hline 3 & $\begin{array}{c}1 \% \text { PET, } \\
10 \% \\
\text { Alccofine }\end{array}$ & 720 & 0.91 & 20 & 10.2 \\
\hline 4 & $\begin{array}{c}1.25 \% \\
\text { PET, } 10 \% \\
\text { Alccofine }\end{array}$ & 580 & 0.77 & 28 & 9 \\
\hline
\end{tabular}




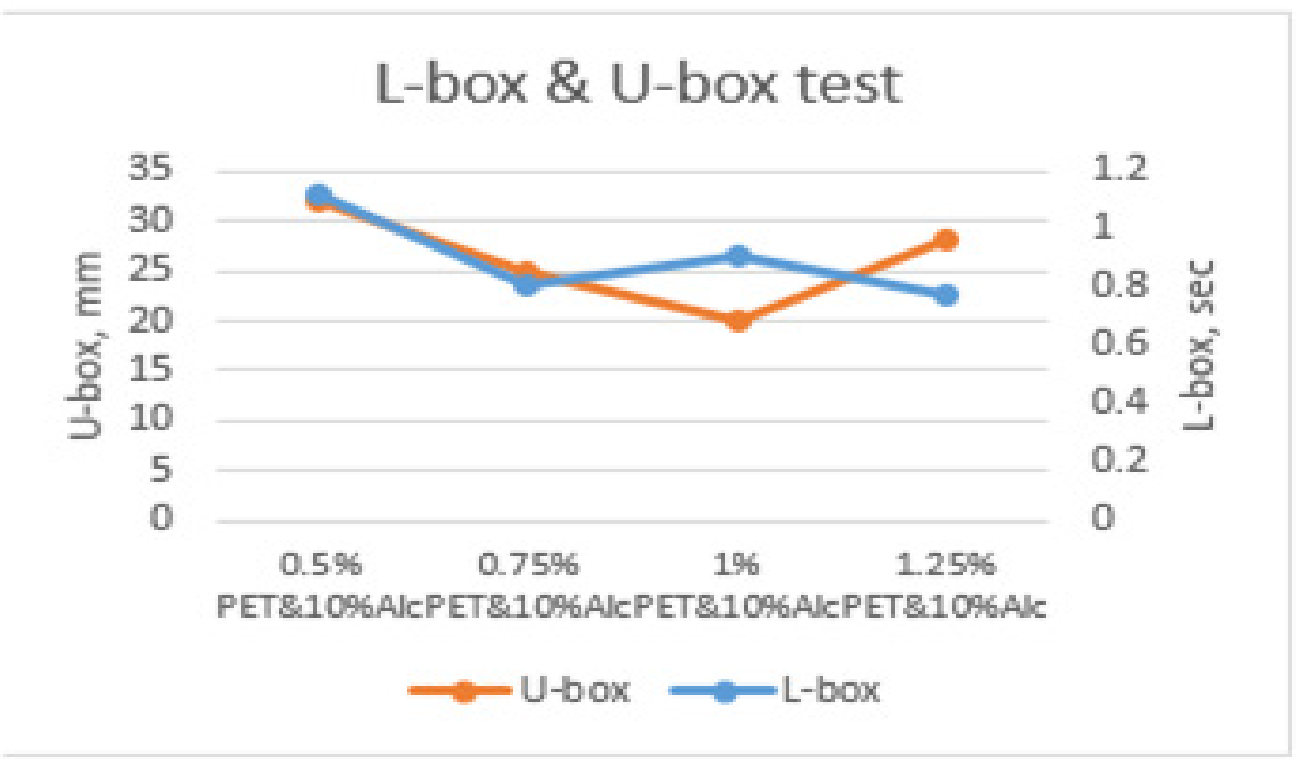

Figure 3. Variation of L-Box test \& U-Box test of SCC Mixes.

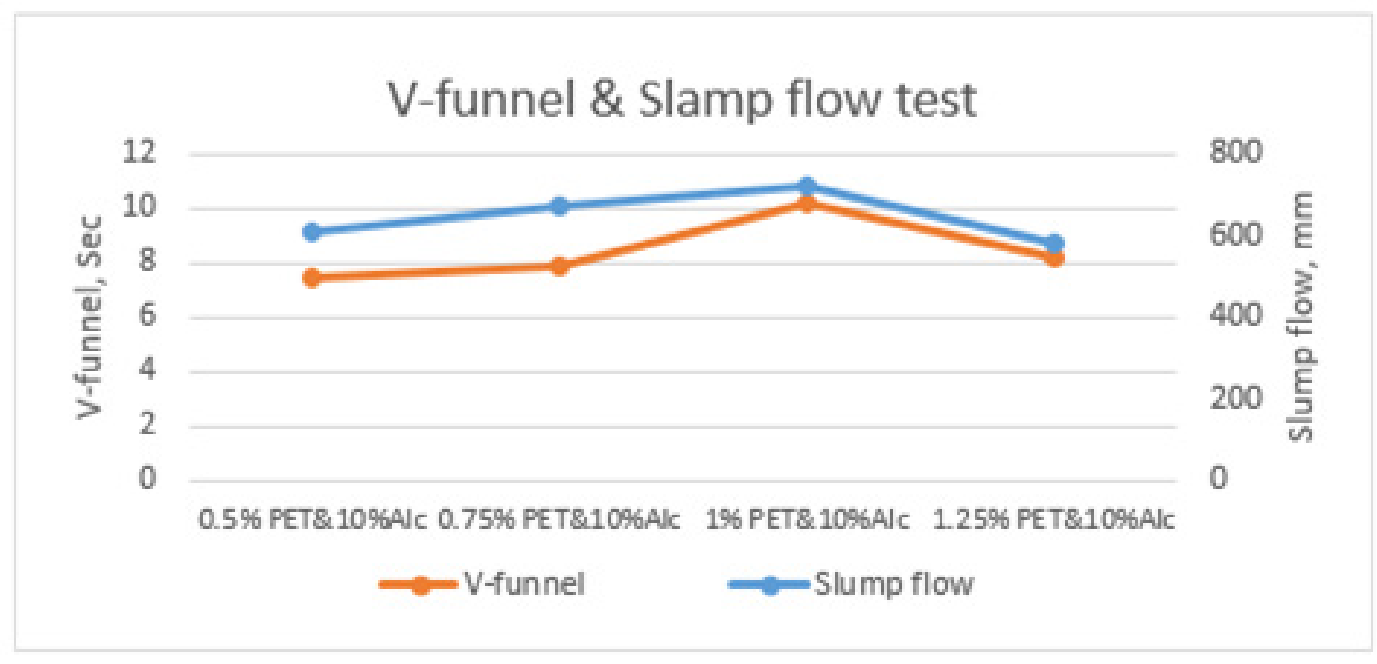

Figure 4. Variation of Slump Flow \& Funnel Tests of SCC for Various Mixes.

Alccofine. After 1\% usage of plastic waste, by increasing the percentage utilizing of plastic waste content the slump flow, V-funnel, L-box and U-box respectively decreased shown in Figure 3. Slump flow test and V-funnel test for $1 \%$ plastic waste and $10 \%$ Alccofine mix was found to be $720 \mathrm{~mm}$ and $10.2 \mathrm{sec}$ respectively which fulfilled the requirement of EFNARC-2005 shown in Figure 4.

\subsection{Mechanical Properties of SCC}

The results for mechanical properties of SCC presented in Table 5. Compressive strength test was increased after 


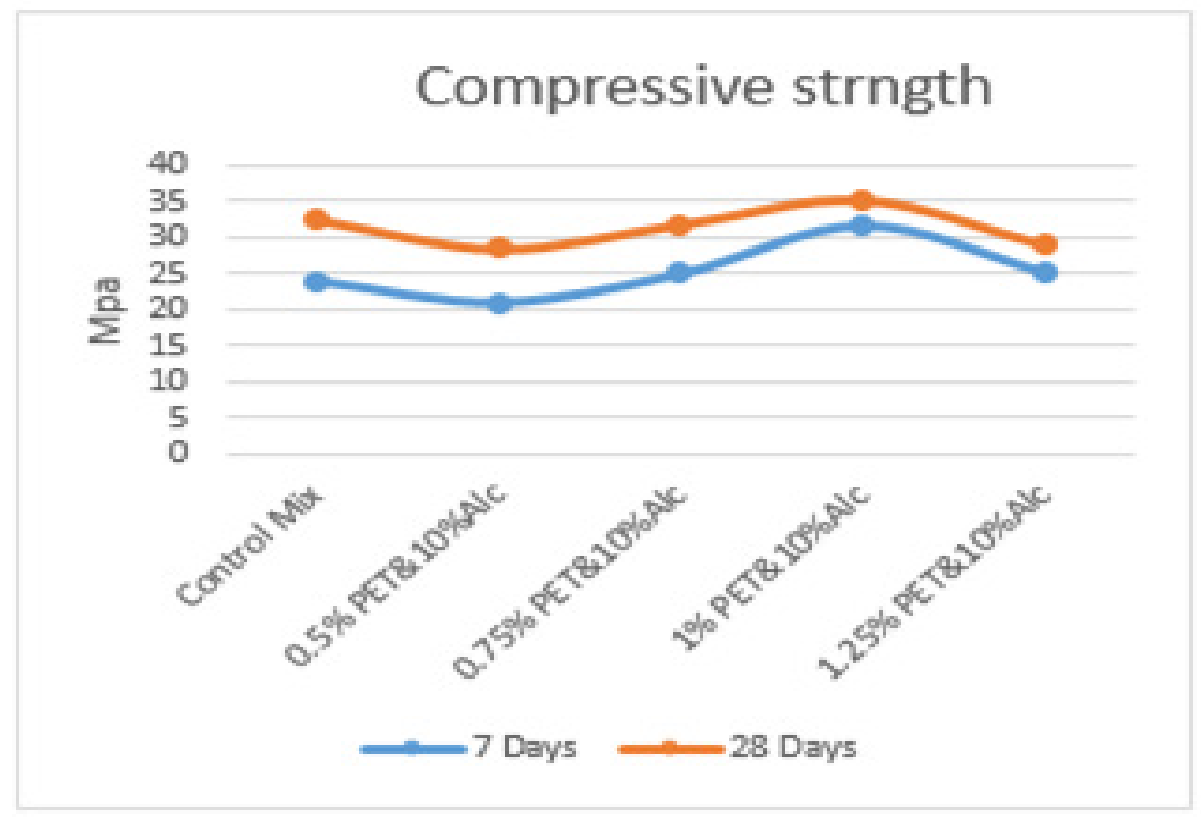

Figure 5. Compressive Strength of SCC for various Mixes.

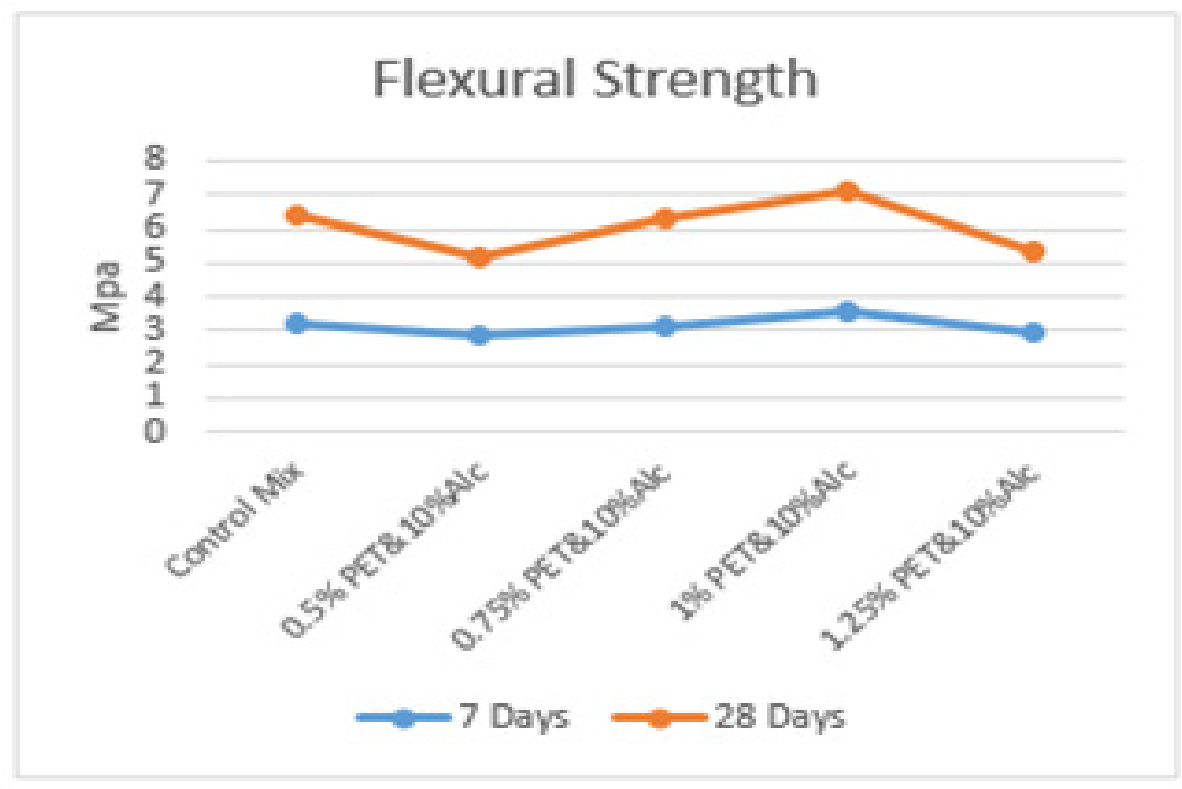

Figure 6. Flexural Strength of SCC for various Mixes.

7 days and 28 days than conventional concrete and from results also obtained SCC mix ( $1 \%$ plastic waste and $10 \%$ Alccofine) have higher compressive strength, by increasing the amount of plastic waste compressive strength have been decreased. Results for 7 days and 28 days' compres- sive strength of SCC mixes are presented in Figure 5. Flexural strength of SCC was found to be increased 1.5\% after 7 days and 2 days respectively than conventional concrete also from flexural test results it observed that mix of $1 \%$ PET and 10\% Alccofine has higher flexural strength 


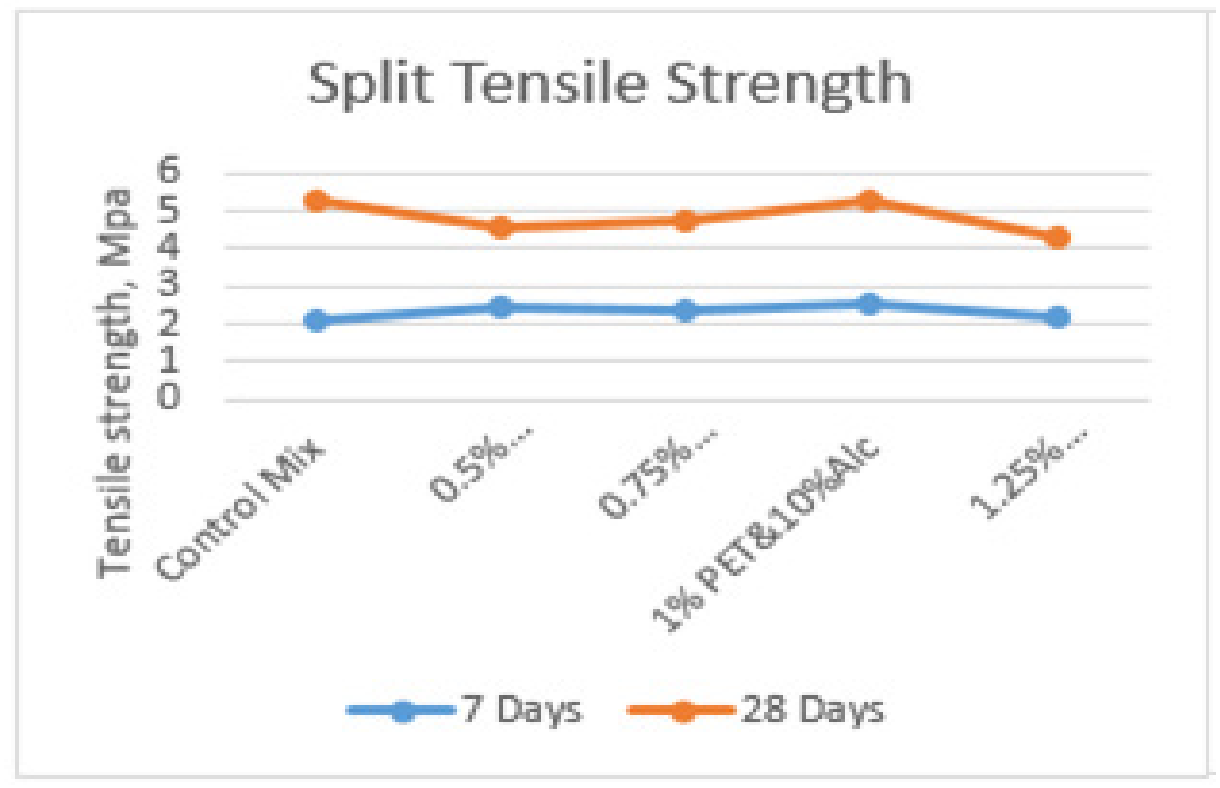

Figure 7. Split Tensile Strength of SCC Mixes.

Table 5. Mechanical properties of SCC Mixes with Alccofine and Plastic waste

\begin{tabular}{|c|c|c|c|c|c|c|c|}
\hline \multirow{2}{*}{$\mathbf{S} / \mathbf{N}$} & \multirow{2}{*}{ Trial Mix } & \multicolumn{2}{|c|}{$\begin{array}{c}\text { Compressive Strength } \\
\text { (Mpa) }\end{array}$} & \multicolumn{2}{|c|}{$\begin{array}{c}\text { Flexural Strength } \\
\text { (Mpa) }\end{array}$} & \multicolumn{2}{|c|}{ Tensile Strength (Mpa) } \\
\hline & & 7 days & 28 days & 7days & 28 days & 7days & 28 days \\
\hline 1 & $\begin{array}{l}\text { Control } \\
\text { Mix }\end{array}$ & 24 & 32.55 & 3.22 & 6.42 & 2.12 & 5.31 \\
\hline 2 & $\begin{array}{c}0.5 \% \\
\text { PET, 10\% } \\
\text { Alccofine }\end{array}$ & 24.6 & 28.55 & 2.81 & 5.12 & 2.42 & 4.55 \\
\hline 3 & $\begin{array}{c}0.75 \% \\
\text { PET, 10\% } \\
\text { Alccofine }\end{array}$ & 27.4 & 31.88 & 3.12 & 6.31 & 2.31 & 4.78 \\
\hline 4 & $\begin{array}{c}1 \% \text { PET, } \\
10 \% \\
\text { Alccofine }\end{array}$ & 31.7 & 35.25 & 3.54 & 7.12 & 2.53 & 5.32 \\
\hline 5 & $\begin{array}{c}1.25 \% \\
\text { PET, } 10 \% \\
\text { Alccofine }\end{array}$ & 25.2 & 29.05 & 2.93 & 5.31 & 2.14 & 4.32 \\
\hline
\end{tabular}


than other mixes presented in Figure 6, the test results for tensile strength presented in Figure 7. As from split tensile test results the optimum result for tensile strength was found with $1 \%$ replacement of plastic waste and $10 \%$ Alccofine. So, in this study trail mix 1\% PET \& $10 \%$ Alccofine has higher strength than other mixes. Table 5 presented the results of hardened properties of SCC.
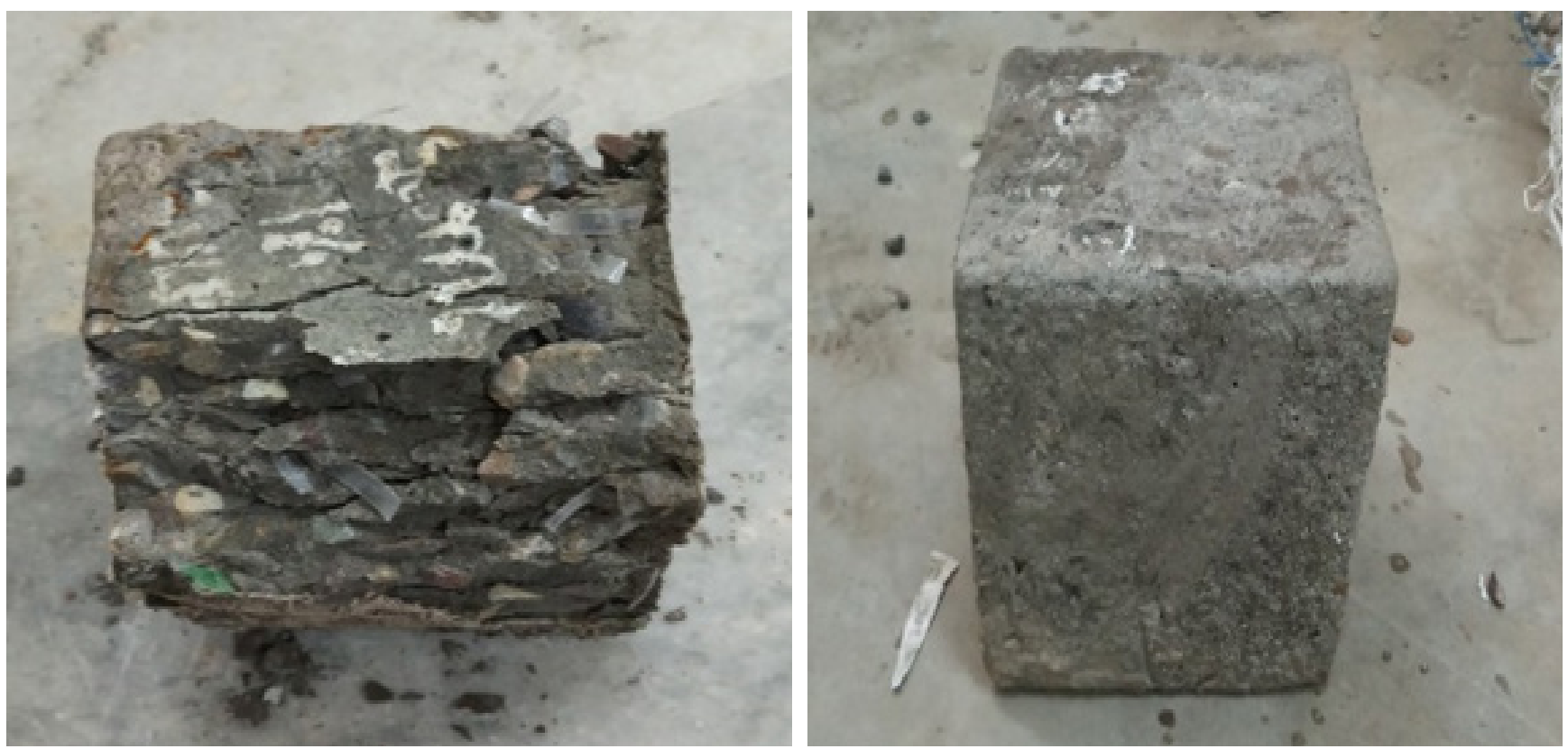

Figure 8. Samples after attacking the Sulphuric Acid.

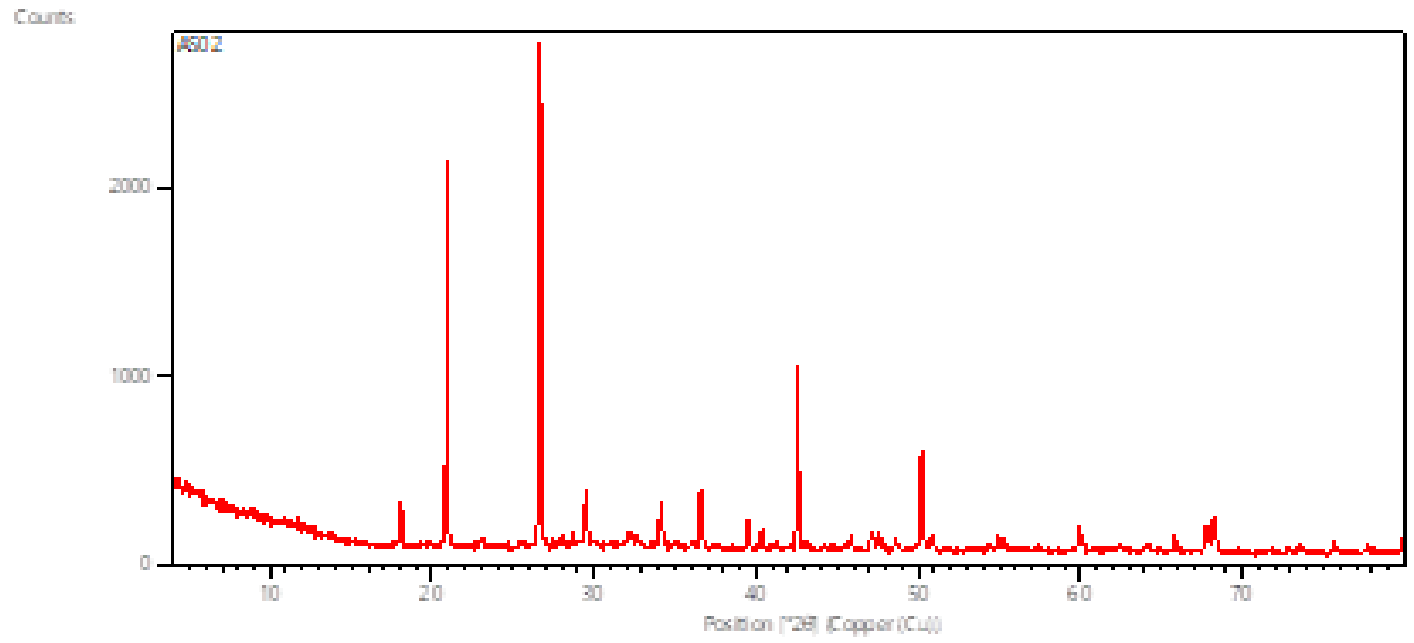

Figure 9. X-Ray Diffraction for SCC Mix (10\% Alccofine \& 1\% PET). 


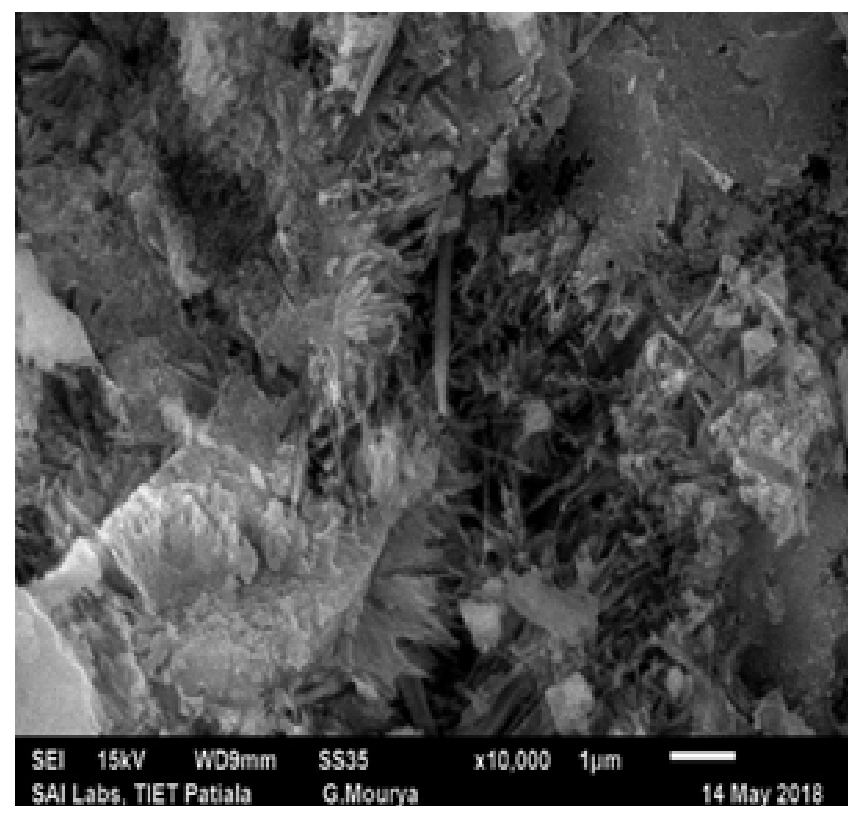

(a)

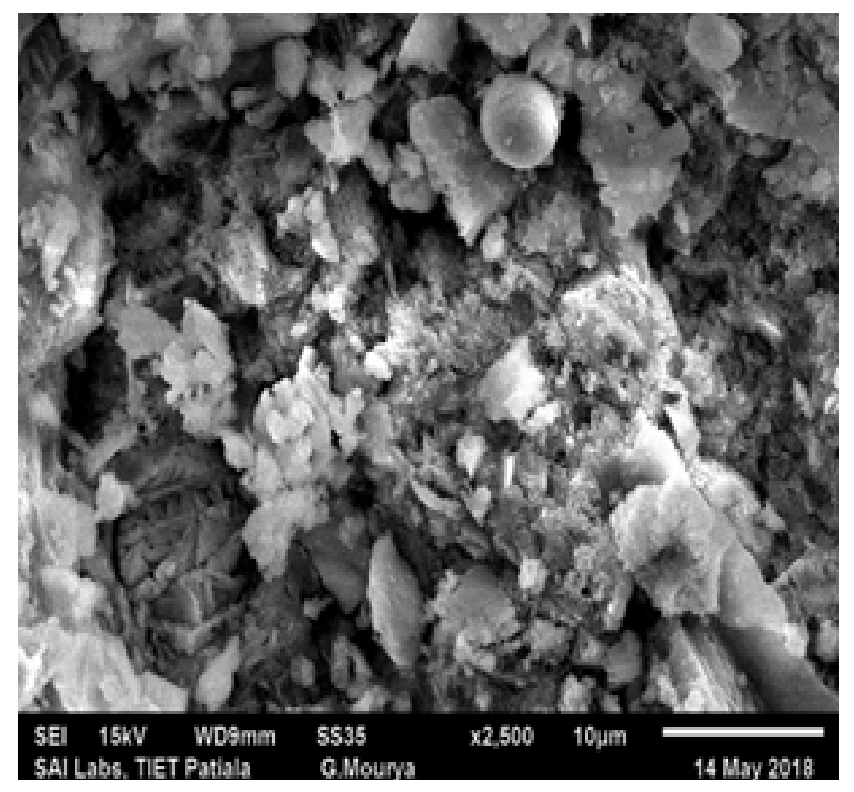

(c)

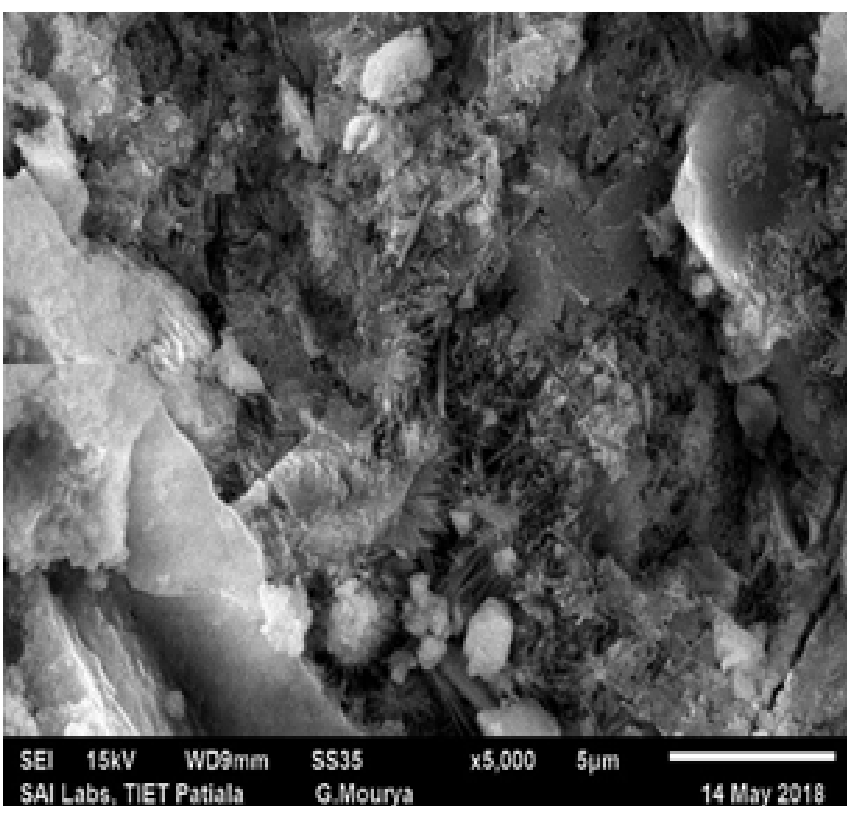

(b)

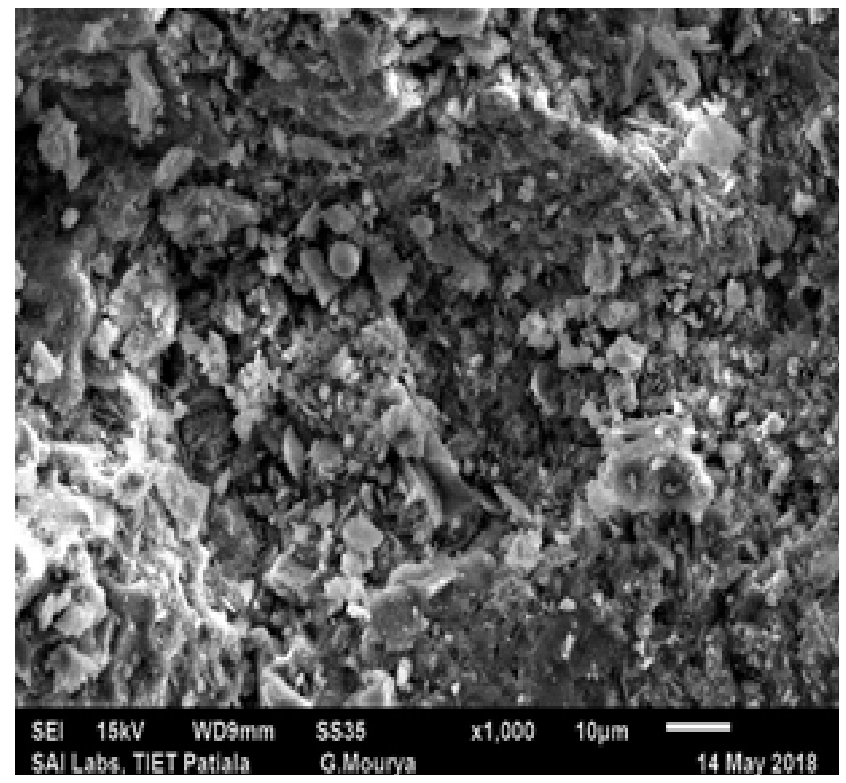

(d)

Figure 10. ( $a, b, c$ and $d$ ) are showing the result for SEM Analysis.

that self-compacting concrete has good resistance when it faced with sulphate attack, the result for sulphate attack abrasion test are shown in Table 6,7 respectively. The X-ray diffraction test result also showed in Figure 8. SEM \& EDS test results presented in Figure 9-11. From the tests results Self compacting concrete has shown excellent properties and shown the higher strength with Alccofine 1203 and Plastic waste (PET) as compared to conventional concrete. Self-compacting concrete has good durability against sulphate attack test, abrasion test, 


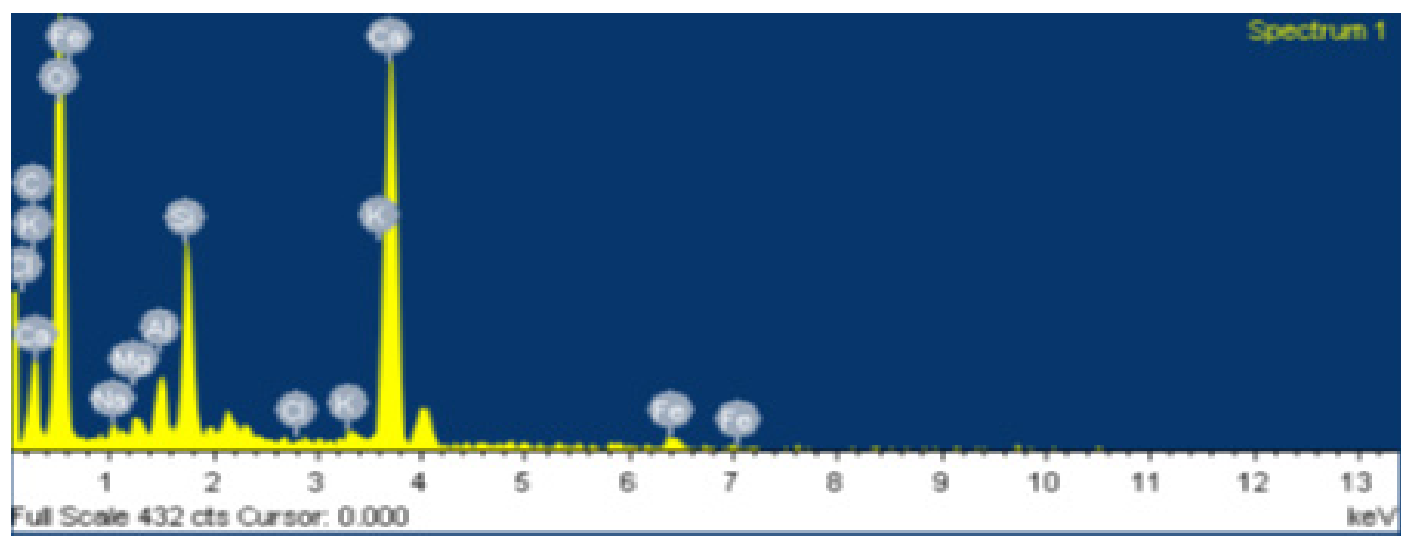

(a)

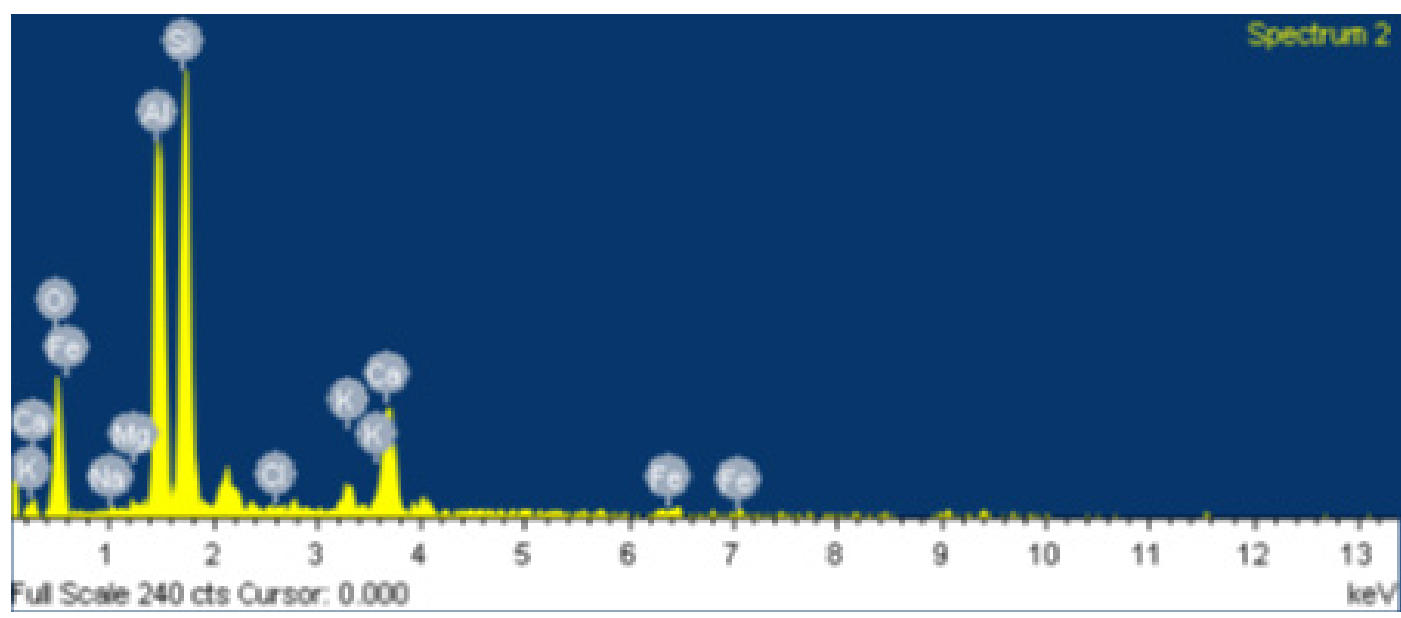

(b)

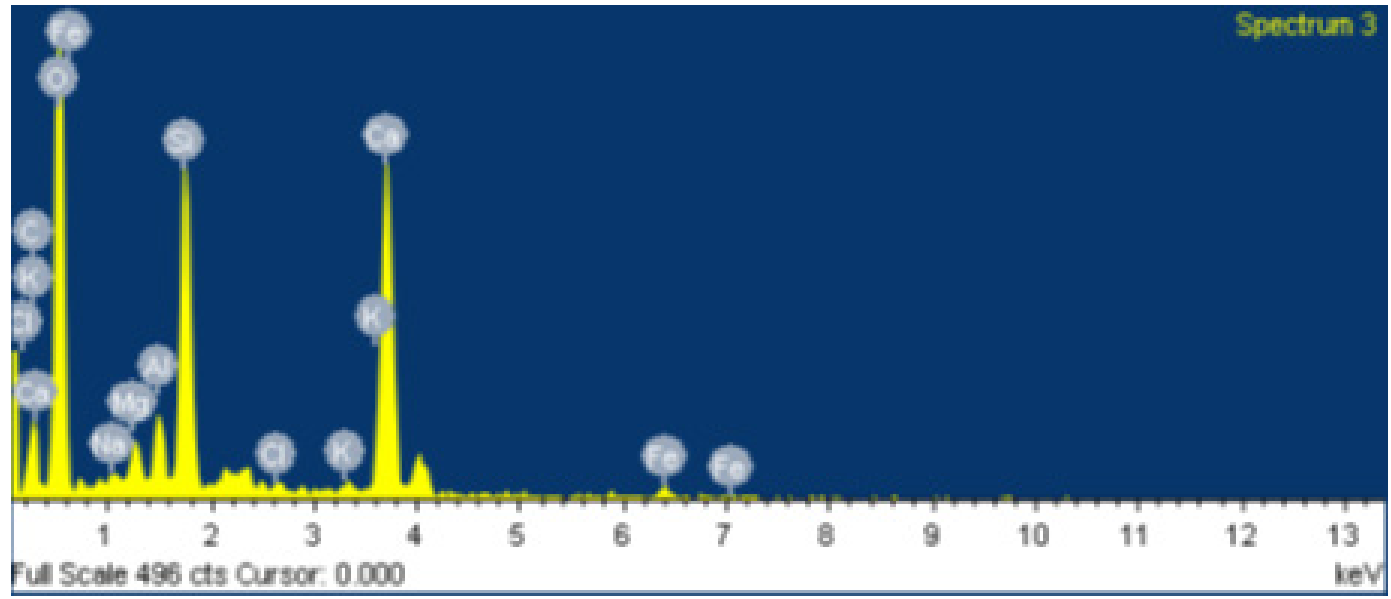

(c)

Figure 11. (a, b \& c ) are results for EDS analysis.

XRD test and SEM \& EDS test. SCC has the same wear and tear readings for abrasion test. From Sulphate attack test it observed a little decreasing the strength of SCC but at all it was good. 
Table 6. Result for Sulphate Attack Test

\begin{tabular}{|c|c|c|c|c|}
\hline S. NO & $\begin{array}{c}\text { Weight of } \\
\text { Sample Before } \\
\text { Immersing in } \\
\text { H2SO4 }\end{array}$ & $\begin{array}{c}\text { Weight Loss of } \\
\text { Sample After } \\
\text { Immersing in } \\
\text { H2SO4 }\end{array}$ & $\begin{array}{c}\text { Different in } \\
\text { Weight }\end{array}$ & $\begin{array}{c}\text { Compressive } \\
\text { Strength of } \\
\text { Sample }\end{array}$ \\
\hline 1 & $8.27 \mathrm{Kg}$ & $8.05 \mathrm{Kg}$ & $1.75 \%$ & $27.5 \mathrm{Mpa}$ \\
\hline
\end{tabular}

Table 7. Result for Abrasion Test

\begin{tabular}{|c|c|c|c|}
\hline S. NO & $\begin{array}{c}\text { Initial Reading } \\
\text { Before Abrasion }\end{array}$ & $\begin{array}{c}\text { Final Reading After } \\
\text { Abrasion }\end{array}$ & Abrasion (\%) \\
\hline 1 & $70 \mathrm{~mm}$ & $69 \mathrm{~mm}$ & 1.42 \\
\hline
\end{tabular}

\subsection{Correlation Coefficient}

The correlation coefficient has been evaluated for this experimental study to find out the relationship between variables (to predict the effect of input parameters to output parameters $)^{18}$. Table 8 presented the result data between input parameter and output parameters which included the database of 4 experimental observations of SCC mixes. Table 9 presented the mean, Standard Deviation (SD) and coefficient of variation. Plastic waste (PET) and fine aggregate are the important parameters for input and output are workability (slump flow, L-box, U-box, and V-funnel) parameters and test for evaluat- ing the strength are output parameters. Input parameters and output parameters are selected based on correlation coefficient $(\mathrm{R})$, and the range of correlation coefficient value is $-1 \leq \mathrm{R} \leq+1$ the $(+)$ values is showing the positive correlation and the (-) values are showing no correlation ${ }^{19}$. The values which are closed to 1 are showing the strongest correlation between tested variables. The PET and fine aggregate are independent parameters which are input values but output values are dependent parameters. As from results it was found that all parameters are effecting in workability and strength value.

Table 8. Statistical value of parameters

\begin{tabular}{|c|c|c|c|c|c|c|c|c|c|}
\hline Properties & PET & F. agg & $\begin{array}{c}\text { Slump } \\
\text { flow }(\mathbf{m m})\end{array}$ & L-Box & $\begin{array}{c}\text { U-Box } \\
(\mathbf{m m})\end{array}$ & $\begin{array}{c}\text { V-Funnel } \\
(\mathbf{s})\end{array}$ & $\begin{array}{c}\text { C.S, Mpa } \\
\text { (28Days) }\end{array}$ & $\begin{array}{c}\text { F.S, Mpa } \\
\text { (28Days) }\end{array}$ & $\begin{array}{c}\text { T.S, Mpa } \\
(\mathbf{2 8 D a y s})\end{array}$ \\
\hline Mean & 20.560 & -0.011 & 0.011 & 0.244 & 0.019 & -0.212 & 0.151 & 0.239 & 0.234 \\
\hline S.D & 7.583 & 0.032 & 0.031 & 0.691 & 0.053 & 0.599 & 0.427 & 0.675 & 0.662 \\
\hline C.O.V & 0.369 & -2.828 & 2.828 & 2.828 & 2.828 & -2.828 & 2.828 & 2.828 & 2.828 \\
\hline
\end{tabular}


Table 9. Cross correlation between input and output parameters

\begin{tabular}{|c|c|c|c|c|c|c|c|c|c|}
\hline & PET & F. agg & $\begin{array}{c}\text { Slump flow } \\
(\mathbf{m m})\end{array}$ & L-Box & $\begin{array}{c}\text { U-Box } \\
(\mathbf{m m})\end{array}$ & $\begin{array}{c}\text { V-Funnel } \\
(\mathbf{s})\end{array}$ & $\begin{array}{c}\text { C.S, } \\
\text { Mpa }\end{array}$ & F.S, Mpa & T.S, Mpa \\
\hline PET & 1 & & & & & & & & \\
\hline F. agg & -1.000 & 1 & & & & & & & \\
\hline $\begin{array}{c}\text { Slump flow } \\
\text { (mm) }\end{array}$ & -0.083 & 0.082 & 1 & & & & & & \\
\hline $\begin{array}{c}\text { L-Box } \\
\text { U-Box (mm) }\end{array}$ & -0.783 & 0.783 & -0.026 & 1 & & & & & \\
\hline $\begin{array}{c}\text { V-Funnel (s) } \\
\text { C.S, Mpa (28 } \\
\text { Days) }\end{array}$ & 0.724 & -0.725 & 0.506 & -0.379 & -0.802 & 1 & & & \\
\hline $\begin{array}{c}\text { F.S, Mpa (28 } \\
\text { Days) }\end{array}$ & 0.192 & -0.192 & 0.961 & -0.275 & -0.967 & 0.672 & 0.995 & 1 & \\
\hline $\begin{array}{c}\text { T.S, Mpa (28 } \\
\text { Days) }\end{array}$ & -0.045 & 0.044 & 0.978 & 0.074 & -0.847 & 0.604 & 0.955 & 0.936 & \\
\hline
\end{tabular}

Note: bold coefficients are significant

\section{Conclusions}

The conclusions can be procured from the various tests that were performed on normal concrete and in Self compacting concrete with utilization of plastic waste (PET) and Alccofine 1203 are:

Self-compacting concrete has best performance in workability and durability with utilization of $10 \%$ Alccofine 1203 and 1\% Plastic waste (PET) as a replacement of cement and fine aggregate respectively.

The optimum percentage for Alccofine and Plastic waste as cement and fine aggregate replacement was achieved to be $10 \%$ Alccofine and $1 \%$ Plastic waste.
By increasing the percentage of plastic waste after $1 \%$, the strength of self-compacting will be decreased.

The maximum strength was achieved with Mix of SCC by $1 \%$ plastic waste and $10 \%$ Alccofine.

In case of strength self-compacting concrete with best percentage has been proved that it has higher strength wit mix of $1 \%$ PET \& $10 \%$ Alccofine.

Self Compacting concrete with using 1\% PET and 10\% Alccofine as a replacement of cement and fine aggregate respectively is more workable and durable than Normal concrete.

Self compacting with utilization of Plastic waste and 
Alccofine is an Eco-friendly concrete which can help to reduce the waste material from environment.

\section{References}

1. Dinesh A, Harini S, Jasmine Jeba P, Jincy J, Shagufta Javed. Experimental study on properties of self-compacting concrete. International journal of research in engineering, science and technologies. 2017; 6(30):1-9.

2. Deepa SA, Hasan K. Study on mechanical and durability properties of Self compacting concrete with proportion of Alccofine and fly-ash. International journal of new innovation in engineering and technology. 2016; 5(1):1-10.

3. Kavitha S, Felix Kala T. Evaluation of strength behavior of self-compacting concrete using alccofine and GGBS as partial replacement of cement. Indian Journal of Science and Technology. 2016; 9(22):1-5. Crossref.

4. Dhiyaneshwaran S, Baskar P. Study on durability characteristic of self-compacted concrete with Alccofine. Jordan journal of civil engineering. 2013; 7(3):1-12.

5. Sanjay S, Jagjeet S. Study on properties of self-compacted concrete with Alccofine and fly ash. International journal for research in applied science and engineering technology. 2017; 4(8):1-4.

6. Balamurugan U, Goutham V. Effective utilization of PET bottles in self-compacting concrete. International conference on emerging trends in engineering, science and technology. 2017; p. 58-62.

7. Sheelan M, Nahla N. Fresh properties of self-compacting concrete with plastic waste as partial replacement of sand. International Journal of Sustainable Built Environment. 2017; 6(2):299-308. Crossref.

8. Mishra M, Panda KC. An Experimental Study on fresh and hardened properties of self compacting Rubberized concrete. Indian Journal of Science and Technology. 2015; 8(29):1-8. Crossref.

9. Al-Hadithi A, Nahla N. The possibility of enhancing some properties of self-compacting concrete by adding waste plastic fibers. Journal of Building Engineering. 2016; 8:2028. Crossref.

10. Specifications for 43 grade Portland cement. Date accessed: 2003: available from: https://archive.org/details/gov. in.is.8112.2013.

11. Specifications for coarse and fine aggregate from natural resource for concrete. Date accessed: 1970: Available from: https://archive.org/details/gov.in.is.383.1970

12. Vijaya GS, Dr. Ghorpade VG, Dr. Rao H. The Behavior of Self Compacting Concrete with Waste Plastic Fibers When Subjected to Chloride Attack. Since Direct PMME. 2018; 5(1):1501-08.

13. Vijaya GS. Waste Plastic Fibre Reinforced Self Compacting Concrete. International Journal of Engineering Research and Applications. 2016; 6(5):27-316.

14. Testing fresh self compacting concrete BS EN 12350 9: 2010, V funnel test. Date accessed: 31/08/2010: Available from: https://shop.bsigroup.com/ProductDetail/? pid $=000000000030210222$

15. Testing fresh self compacting concrete, BS EN 12350 8: 2010, L box test. Date accessed: 31/08/2010: Available from: https://shop.bsigroup.com/ProductDetail/? pid=000000000030210219

16. Testing fresh self compacting concrete, BS EN 12350 8: 2010, slump flow test. Date accessed: 31/08/2010: Available from: https://shop.bsigroup.com/ProductDetail/ ?pid=000000000030210219

17. Specifications and guidelines for self-compacting concrete. Date accessed: 02/2002: Available from: http://www.efnarc. org/pdf/SandGforSCC.PDF

18. G. Vijaya. The Behavior of Self Compacting Concrete with Waste Plastic Fibers When Subjected to Acid Attack. International Journal of Engineering and Technology (IJET). 2016; 8(3):1-7.

19. Nayan N, Prashant K. Experimental Study on SelfCompacting Concrete using E-plastic waste materials in partial replacement of coarse aggregate. Journal of Emerging Technologies and Innovative Research. 2017; $4(4): 1-11$. 